\title{
Task 2.0 - Air Quality Assessment, Control, and Analytical Methods \\ Subtask 2.11 - Lactic Acid FGD Additives from Sugar Beet Wastewater
}

\author{
Final Report \\ June 1998
}

\author{
By: \\ Edwin S. Olson
}

Work Performed Under Contract No.: DE-FC21-93MC30097

For

U.S. Department of Energy

Office of Fossil Energy

Federal Energy Technology Center

P.O. Box 880

Morgantown, West Virginia 26507-0880

By

Energy \& Environmental Research Center

University of North Dakota

P. O. Box 9018

Grand Forks, North Dakota 58202-9018

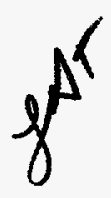




\section{Disclaimer}

This report was prepared as an account of work sponsored by an agency of the United States Government. Neither the United States Government nor any agency thereof, nor any of their employees, makes any warranty, express or implied, or assumes any legal liability or responsibility for the accuracy, completeness, or usefulness of any information, apparatus, product, or process disclosed, or represents that its use would not infringe privately owed rights. Reference herein to any specific commercial product, process, or service by trade name, trademark, manufacturer, or otherwise does not necessarily constitute or imply its endorsement, recommendation, or favoring by the United States Government or any agency thereof. The views and opinions of authors expressed herein do not necessarily state or reflect those of the United States Government or any agency thereof. 


\section{DISCLAIMER}

Portions of this document may be illegible in electronic image products. Images are produced from the best available original document. 
TABLE OF CONTENTS

LIST OF FIGURES $\ldots \ldots \ldots \ldots \ldots \ldots \ldots \ldots \ldots \ldots \ldots \ldots \ldots \ldots \ldots \ldots \ldots \ldots \ldots \ldots \ldots$ ii

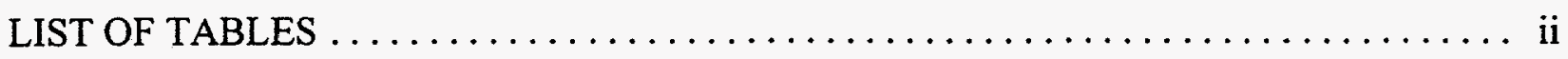

INTRODUCTION $\ldots \ldots \ldots \ldots \ldots \ldots \ldots \ldots \ldots \ldots \ldots \ldots \ldots \ldots \ldots \ldots \ldots \ldots \ldots \ldots \ldots \ldots$

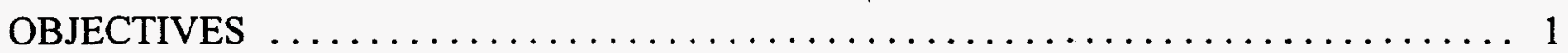

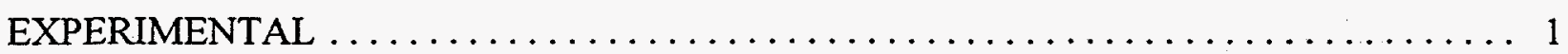

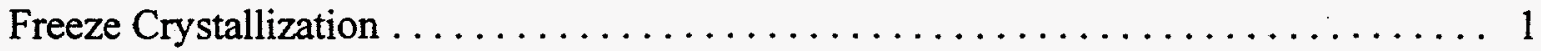

Lactate Concentrations ..................................... 2

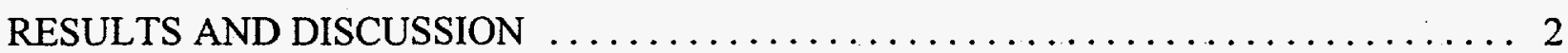

Freeze Crystallization $\ldots \ldots \ldots \ldots \ldots \ldots \ldots \ldots \ldots \ldots \ldots \ldots \ldots \ldots \ldots \ldots \ldots \ldots \ldots \ldots, 2$

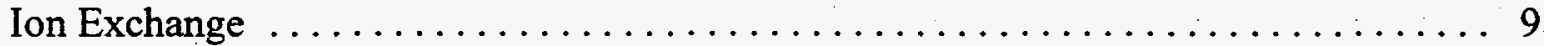

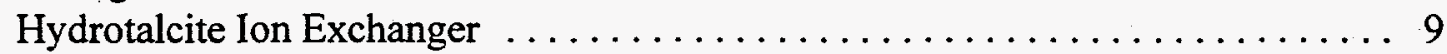

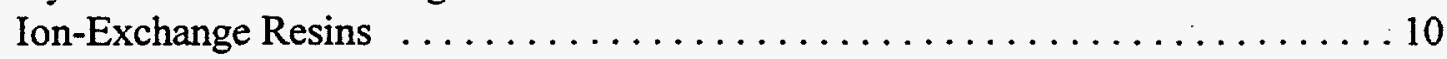

Dual-Sorbent Ion Exchangers ............................ 10

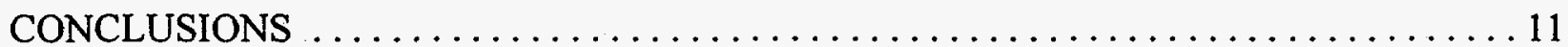




\section{LIST OF FIGURES}

1 FTE $^{\circledast}$ simulator temperature versus time (freeze-thaw simulation of ACS wastewater) $\ldots .3$

2 Equipment configuration for the bench-scale FTE $^{\otimes}$ process simulations $\ldots \ldots \ldots \ldots \ldots 4$

3 Electrical conductivity of melt fractions (freeze-thaw simulation of ACS wastewater) $\ldots .5$

$4 \mathrm{FTE}^{\mathbb{\otimes}}$ simulation product yield (freeze-thaw simulation of ACS wastewater) $\ldots \ldots \ldots \ldots 6$

5 Correlation of electrical conductivity and lactate concentration $\ldots \ldots \ldots \ldots \ldots \ldots 7$

\section{LIST OF TABLES}

1 Lactate Concentrations in Composite Fractions from Freeze Crystallization $\ldots \ldots \ldots \ldots 8$

2 Conductivity, $\mathrm{pH}$, and Dissolved and Suspended Solids Data for Composites ........9 


\section{DISCLAIMER}

This report was prepared as an account of work sponsored by an agency of the United States Government. Neither the United States Government, nor any agency thereof, nor any of their employees makes any warranty, express or implied, or assumes any legal liability or responsibility for the accuracy, completeness, or usefulness of any information, apparatus, product, or process disclosed or represents that its use would not infringe privately owned rights. Reference herein to any specific commercial product, process, or service by trade name, trademark, manufacturer, or otherwise does not necessarily constitute or imply its endorsement, recommendation, or favoring by the United States Government or any agency thereof. The views and opinions of authors expressed herein do not necessarily state or reflect those of the United States Government or any agency thereof.

This report is available to the public from the National Technical Information Service, U.S. Department of Commerce, 5285 Port Royal Road, Springfield, VA 22161; phone orders accepted at (703) $487-4650$.

\section{EERC DISCLAIMER}

LEGAL NOTICE This research report was prepared by the Energy \& Environmental Research Center (EERC), an agency of the University of North Dakota, as an account of work sponsored by the U.S. Department of Energy (DOE). Because of the research nature of the work performed, neither the EERC nor any of its employees makes any warranty, express or implied, or assumes any legal liability or responsibility for the accuracy, completeness, or usefulness of any information, apparatus, product, or process disclosed, or represents that its use would not infringe privately owned rights. Reference herein to any specific commercial product, process, or service by trade name, trademark, manufacturer, or otherwise does not necessarily constitute or imply its endorsement or recommendation by the EERC.

\section{ACKNOWLEDGMENT}

This report was prepared with the support of the DOE Federal Energy Technology Center Cooperative Agreement No. DE-FC21-93MC30097. However, any opinions, findings, conclusions, or recommendations expressed herein are those of the authors(s) and do not necessarily reflect the views of DOE. 


\section{TASK 2.0 - AIR QUALITY ASSESSMENT, CONTROL, AND ANALYTICAL METHODS}

\section{Subtask 2.11 - Lactic Acid FGD Additives from Sugar Beet Wastewater}

\section{INTRODUCTION}

Organic buffers maintain the $\mathrm{pH}$ of the scrubber slurry in flue gas desulfurization as the $\mathrm{SO}_{2}$ dissolves at the air-liquid interface. Inexpensive acids with an appropriate $\mathrm{pKa}$ are required for this application. The pKa of lactic acid (3.86) is between that of the interface and the recirculating slurry and will make soluble calcium ions available in large amounts. Currently lactic acid is somewhat expensive for this use, but the project work will lead to development of a new source of inexpensive lactate.

Microbial action during the storage and processing of sugar beets forms lactic acid in concentrations as high $14 \mathrm{~g} / \mathrm{L}$ in the processing water. The concentrations are lower than those occurring in conventional fermentation production of lactic acids, but since a considerable amount of water ( 5 million gal/day) is involved in the processing of sugar beets in the Red River Valley, a substantial amount ( 90 million $\mathrm{lb} / \mathrm{yr}$ ) of lactic acid or calcium lactate could be recovered as a byproduct for use in flue gas desulfurization (FGD) and other applications. The feasibility of two novel lactate recovery schemes applicable to dilute streams was evaluated in the project.

\section{OBJECTIVES}

The project objective was to evaluate two novel methods for recovering and processing the lactic and other volatile acid byproducts produced during the processing of sugar beets. These methods are 1) freeze crystallization concentration of lactic acid and 2) ion exchange of lactate with recovery as the ester. In the first quarter, bench-scale testing of the freeze-crystallization concept was performed at B.C. Technologies using its freeze-thaw simulation method, and analysis of the recovered fractions was performed at the Energy \& Environmental Research Center. In the second semiannual period, ion-exchange methods were investigated for concentrating lactic acid. These methods employed novel inorganic ion exchangers that have the potential for eliminating fouling by the large amount of the other organic materials present in the water. These include carbohydrates, betaine, and proteins that bind irreversibly to organic ionexchange resins and significantly reduce their capacity and regeneration capability.

\section{EXPERIMENTAL}

\section{Freeze Crystallization}

A simulation experiment was performed in a bench-scale refrigeration unit at B.C. Technologies using temperatures and scaled durations typical of North Dakota and Minnesota 
winters. Monthly average daily temperatures were simulated at the scale of 72 hours for each month. Thus, 6 months of low-temperature conditions were simulated over 18 days in the experiment. Figure 1 is a plot of temperature versus time for the experiment.

A large sample (53 kg) of actual American Crystal Sugar (ACS) wastewater was thawed and used in the simulation. The lactic acid content of this sample was $7.2 \mathrm{~g} / \mathrm{L}(0.72 \mathrm{wt} \%)$. There is a small amount of calcium and other cations in the water sample. The $\mathrm{pH}$ of the sample is 4.77. This means that most of the lactic acid is present as the acid rather than as a lactate salt. At a pH of 3.86, the concentration of lactic acid and lactate would be equal.

The apparatus consists of a 38- $\times 31-\times 73$-in. refrigeration unit with a sloped freezing pad on the bottom (Figure 2). Water is introduced through the top of the unit from a holding tank and drips on the freezing pad. Runoff from the freezing pad will flow out of the unit though a series of valves and collection units. The first collection is for the concentrated brine runoff. The brine conductivity is measured and must be relatively high to actuate the valve. Otherwise, it is returned to the holding tank. The second collection is for the runoff of melted ice (treated water), which will exhibit a very low conductivity $(<1 \mathrm{mS} / \mathrm{cm})$.

\section{Lactate Concentrations}

Concentrations of lactic and other acids in each of the composite splits were determined by a calibrated high-performance liquid chromatography (HPLC) method. The method uses an Aminex HPX-87H ion-exclusion column, with dilute sulfuric acid $(0.01 \mathrm{~N})$ as the eluent. A UV detector monitors the elution of acids and other organics at $211 \mathrm{~nm}$. The flow rate is constant at $0.9 \mathrm{~mL} / \mathrm{min}$ (Waters ${ }^{\mathrm{TM}}$ pump). Five concentrations of lactic and other acids were used for the calibration curve, which was linear over the range of 10,000 to $100 \mathrm{mg} / \mathrm{L}$. Composite samples were centrifuged and diluted 1:10 for the analysis. Suspended material was determined, and a sample was evaporated to determine total dissolved solids.

\section{RESULTS AND DISCUSSION}

\section{Freeze Crystallization}

The simulation employed $53.0 \mathrm{~kg}$ of ACS wastewater feed and ran for 18 days. The product fractions collected in the experiment weighed $51.2 \mathrm{~kg}(96.7 \%$ recovery). Twenty-eight product fractions were collected and then combined into seven composite splits. The electrical conductivity of the fractions are plotted in Figure 3. The composite splits consisted of two brine splits, two intermediate splits, and three treated water splits. The product yields by split are illustrated in Figure 4.

Lactic acid is the major component of the ACS wastewater. Several other carboxylic acids are also present. To determine how the concentration of lactic acid relates to the conductivity, which was the monitoring method in the simulation, the conductivity of a series of lactic acid solutions of known concentrations was determined. The results are plotted in Figure 5. A linear relationship between the lactic acid concentration and conductivity was demonstrated. Thus, 


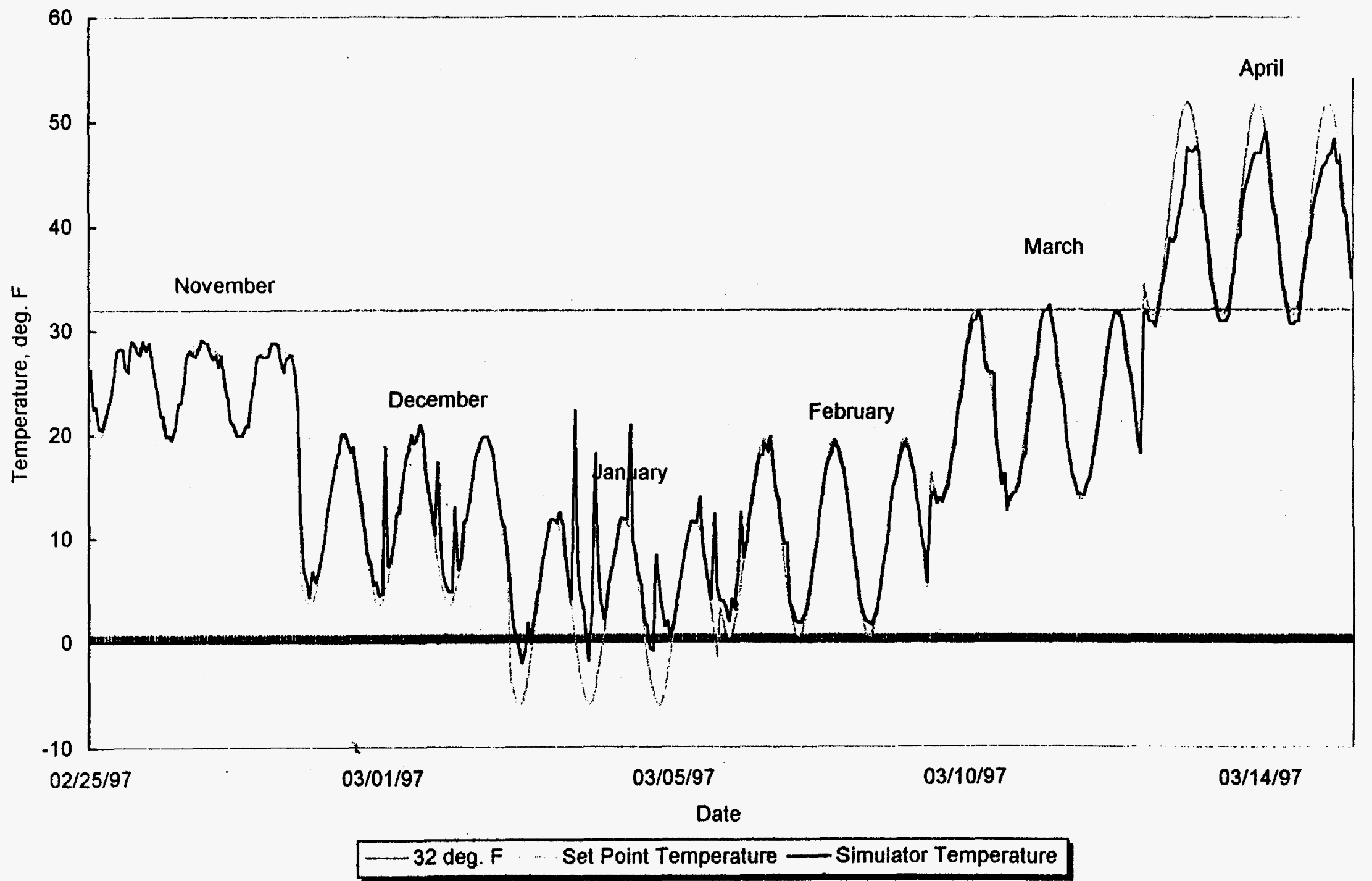

Figure 1. FTE ${ }^{\circledast}$ simulator temperature versus time (freeze-thaw simulation of ACS wastewater). 


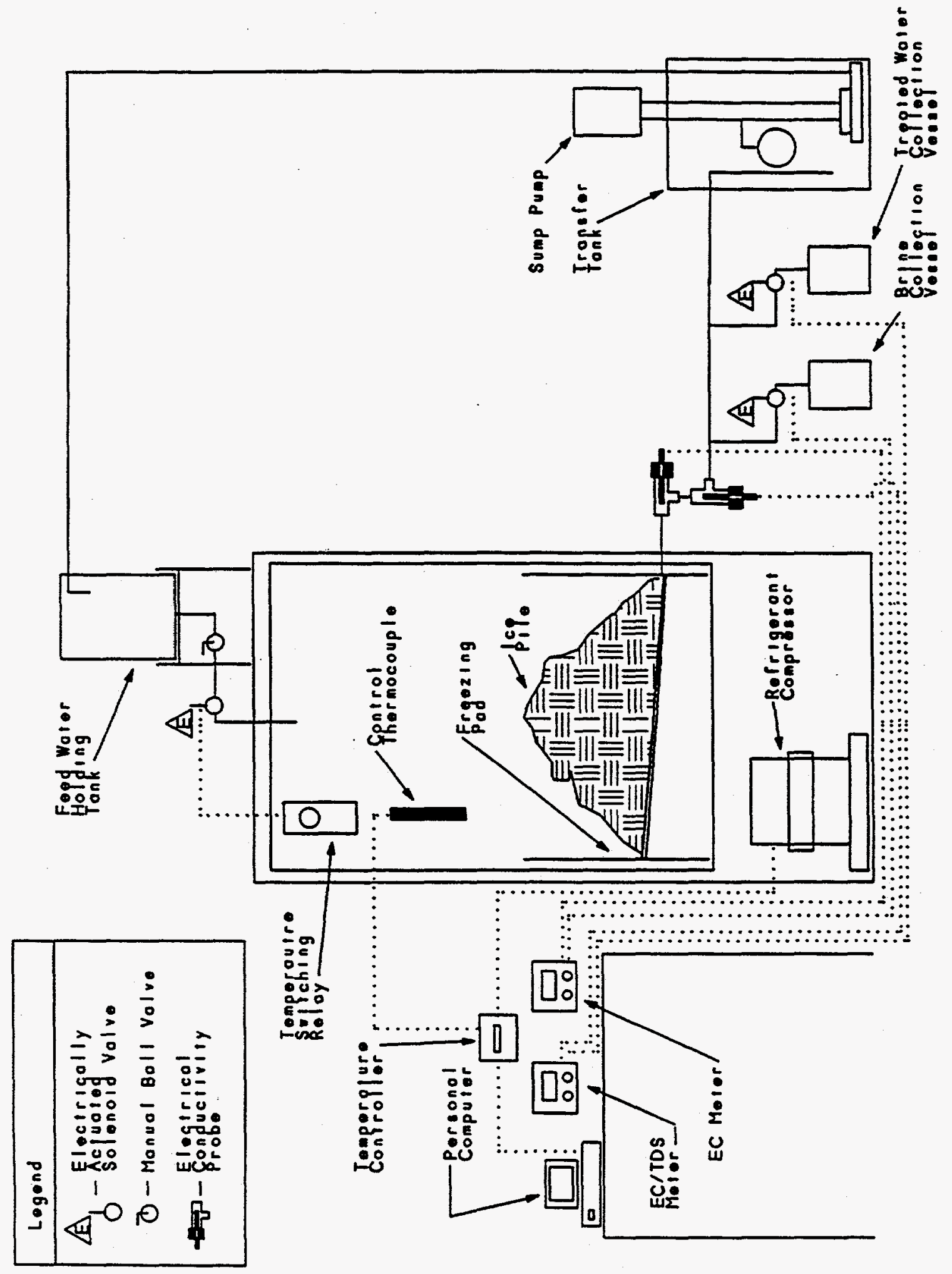

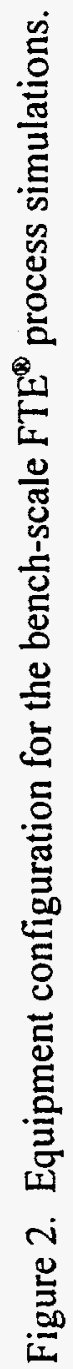




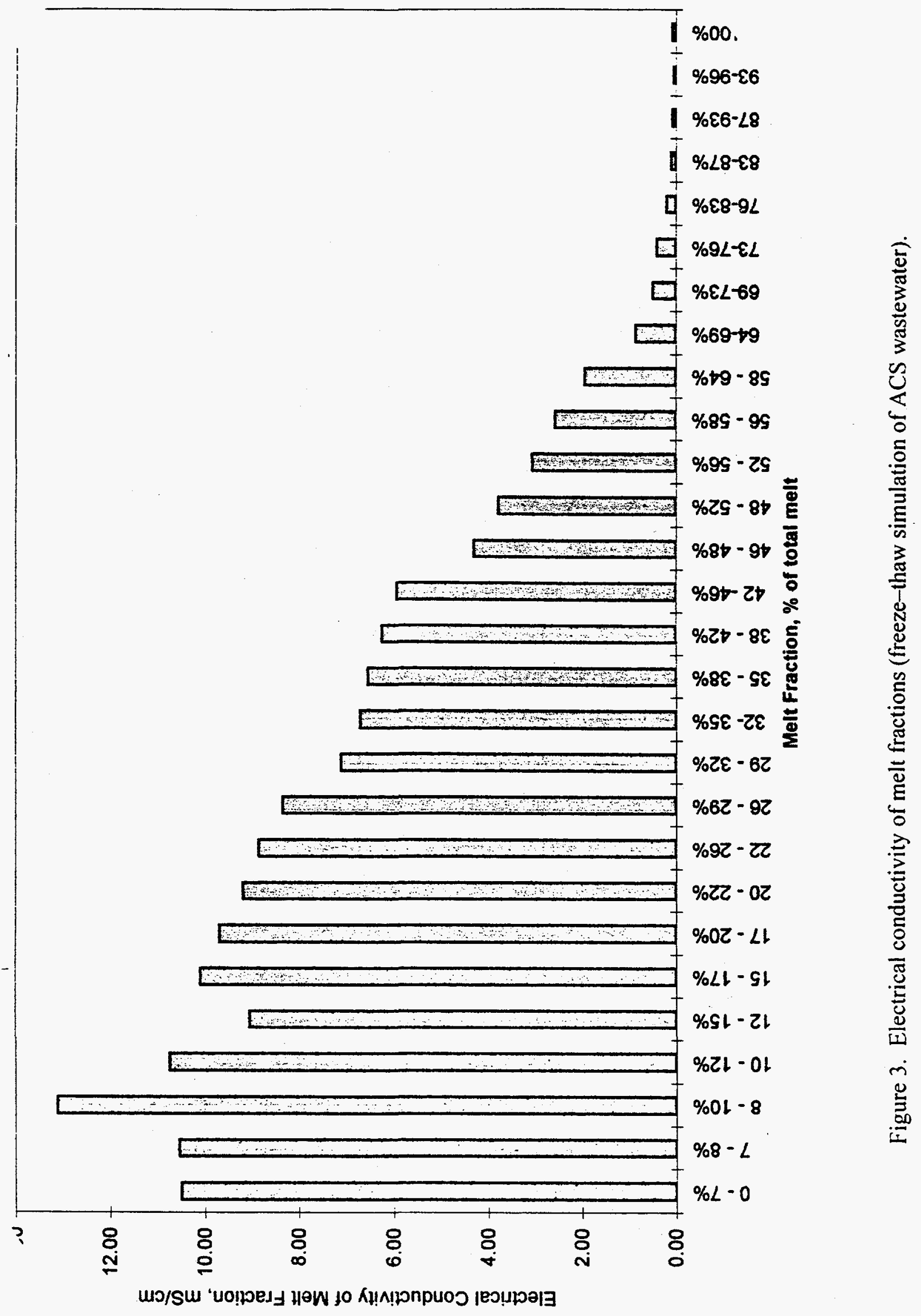




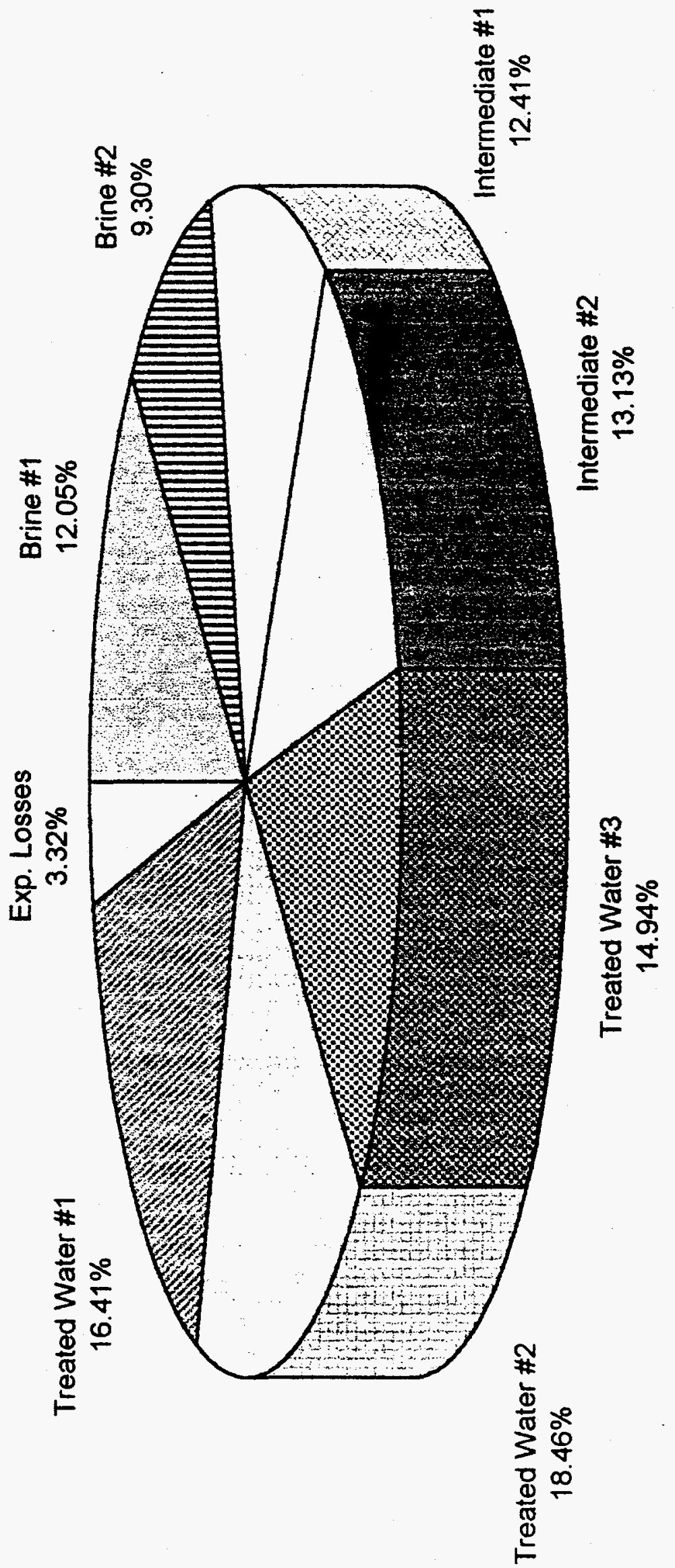

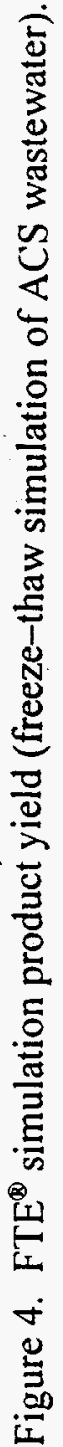




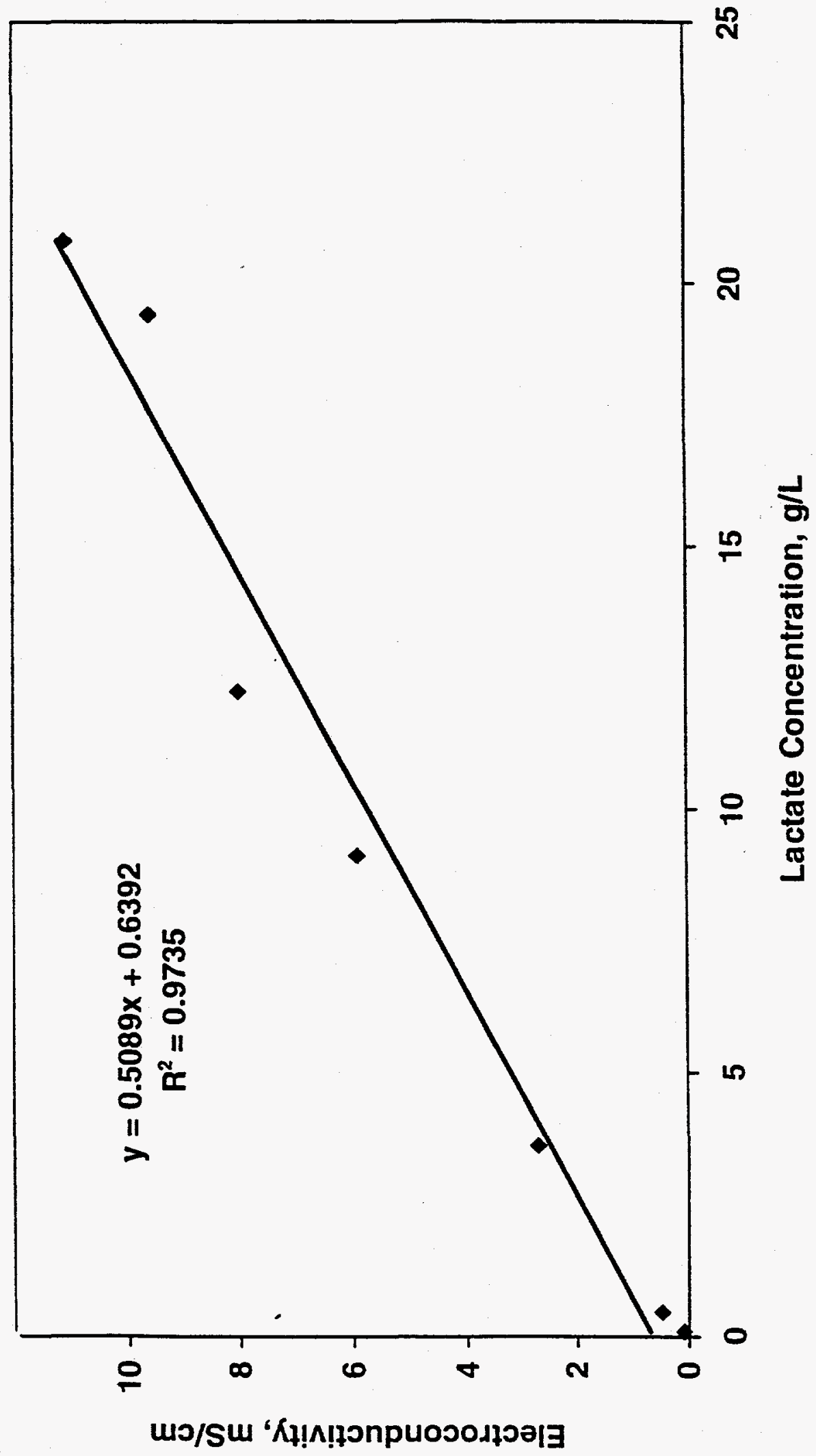

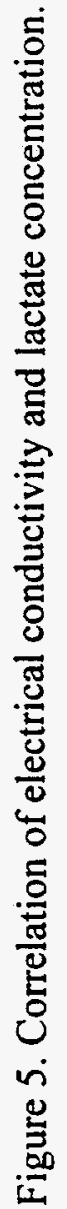


determining the conductivity in the freeze-thaw simulation should be a reliable way to operate the switching in the process.

The lactic acid concentrations of the composite product fractions were determined and the results are shown in Table 1. The percentage of the original lactate appearing in each fraction ("lactate recovered") was also calculated from the weight of the fraction and the concentration. The total of these percentages is $97 \%$. This matches the water recovered exactly. Thus no lactate disappears in the processing.

\section{TABLE 1}

Lactate Concentrations in Composite Fractions from Freeze Crystallization

\begin{tabular}{lcccc}
\hline Sample & $\begin{array}{c}\text { Yield as } \\
\text { Percent of Feed }\end{array}$ & $\begin{array}{c}\text { EC, } \\
\mathrm{mS} / \mathrm{cm}\end{array}$ & $\begin{array}{c}\text { Lactate } \\
\text { Concentration, } \\
\mathrm{g} / \mathrm{L}\end{array}$ & $\begin{array}{c}\text { Lactate Recovered, } \\
\%\end{array}$ \\
\hline Feed & & 5.34 & 7.82 & 32 \\
Brine 1 & 12 & 11.1 & 20.8 & 23 \\
Brine 2 & 9.3 & 9.6 & 19.4 & 19 \\
Intermediate 1 & 12.4 & 8 & 12.2 & 15 \\
Intermediate 2 & 13.1 & 5.9 & 9.12 & 7 \\
TW 3 & 14.9 & 2.7 & 3.61 & 1 \\
TW 2 & 18.5 & 0.5 & 0.46 & 0 \\
TW 1 & 16.4 & 0.1 & 0.09 & \\
\hline
\end{tabular}

Notes:

$\mathrm{EC}=$ electrical conductivity.

Total lactate recovery is $97 \%$ of theoretical.

Brine fractions represent about a threefold increase in lactate concentration.

Treated water (TW) fractions 1 and 2 have lactate concentrations that are $1 \%$ and $6 \%$ of the feed, respectively.

The two brine fractions were high in lactate $(2.6$ times the feed concentration of $7.82 \mathrm{~g} / \mathrm{L})$. Thus, the goal of 10 times concentration was not achieved in the simulation. However, the two brine samples represent $55 \%$ of the lactate recovered. Other carboxylic acids were similarly concentrated in the brine fractions. The lactic acid in two intermediate fractions has also been concentrated $(12.2$ and $9.1 \mathrm{~g} / \mathrm{L})$ with respect to the feed.

Two of the treated water samples were very low in lactic acid and represent $35 \%$ of the feedwater. Thus, a substantial part of the product fractions could possibly be discharged without further treatment.

Further testing of the composite product fractions showed a variance of the $\mathrm{pH}$ of the fractions (Table 2). The $\mathrm{pH}$ of the brine samples was 4.62 and 4.69 , as expected for the higher acid concentrations. The pHs of the treated water samples $(5.34-4.79)$ were substantially 
TABLE 2

Conductivity, $\mathrm{pH}$, and Dissolved and Suspended Solids Data for Composites

\begin{tabular}{lccccc}
\hline Sample & $\mathrm{EC}, \mathrm{mS}$ & $\mathrm{pH}\left({ }^{\circ} \mathrm{C}\right)$ & $\mathrm{TS},{ }^{1} \mathrm{~g} / \mathrm{L}$ & $\mathrm{TSS},{ }^{2} \mathrm{~g} / \mathrm{L}$ & $\mathrm{TDS}^{3} \mathrm{~g} / \mathrm{L}$ \\
\hline Composite Feed & 5.34 & $4.77(22.4)$ & 27.6 & 0.2 & 27.4 \\
Brine 1 & 11.10 & $4.62(22.5)$ & 75.1 & 2.0 & 73.1 \\
Brine 2 & 9.57 & $4.69(25.0)$ & 64.5 & 1.9 & 62.6 \\
TW 1 & 0.082 & $5.34(19.0)$ & 0.6 & 0.6 & 0.0 \\
TW 2 & 0.48 & $4.79(10.0)$ & 0.6 & 0.4 & 0.2 \\
TW 3 & 2.71 & $4.95(18.0)$ & 8.8 & 0.3 & 8.5 \\
Intermediate 1 & 7.97 & $4.74(22.0)$ & 45.9 & 2.7 & 43.2 \\
Intermediate 2 & 5.88 & $4.70(24.5)$ & 26.9 & 1.1 & 25.8 \\
\hline
\end{tabular}

${ }^{1}$ Total solids.

${ }^{2}$ Total suspended solids.

${ }^{3}$ Total dissolved solids.

higher than the $\mathrm{pH}$ of the feed (4.77). The significance of these data is that the cations associated with lactate are concentrated at the same time as the lactate, but not necessarily to exactly the same degree.

Total dissolved solids were determined by evaporation of samples of the composite product fractions. These results (Table 2) are in agreement with the lactic acid concentration data. Lactic acid is the main component, and the other acids should be concentrated to a similar extent in the processing.

\section{Ion Exchange}

Several types of ion-exchange materials were utilized to remove and concentrate lactic and volatile acids from the process water. These include an inorganic hydrotalcite material, a conventional ion-exchange resin, and a new type of silica-based ion exchanger that has ionexchange groups in the pores and a nonadsorptive phase on the surface.

\section{Hydrotalcite Ion Exchanger}

A previous treatment of the sugar beet wastewater with the inorganic hydrotalcite exchanger showed that the acids were removed along with other organic materials, leaving the water with only $500 \mathrm{ppm}$ chemical oxygen demand and suitable for discharge without further anaerobic treatment. The inorganic ion exchanger is a form of magnesium aluminum hydrotalcite, prepared in such a way as to have very high exchange rate for organic anions. This material was synthesized at Universal Fuel Development Associates and was demonstrated to be very effective for removal of humates from surface waters draining peat basins in northern Minnesota. The advantage of the inorganic exchanger is that it can be regenerated thermally. Thus, calcining at $400^{\circ} \mathrm{C}$ completely removes all organic matter by catalytically converting to carbon dioxide and water. 
The calcined hydrotalcite was stirred rapidly with the neutralized wastewater. HPLC analysis of the supernatant water from the hydrotalcite exchanger demonstrated that the hydrotalcite ion exchanger removed $90 \%$ to $95 \%$ of the lactic acid, along with most of the other organic material in the wastewater. The equilibrium capacity of the hydrotalcite was determined to be $211 \mathrm{mg}$ lactate $/ \mathrm{g}$ hydrotalcite.

Several methods were attempted for desorption of the lactic acid from the hydrotalcite. Exchange of the used hydrotalcite with sodium bicarbonate solution removed only $4 \%$ of the lactate. Sodium hydroxide was also ineffective. Thus, lactate is much more strongly bonded to the hydrotalcite layers than the bicarbonate and hydroxide.

Formation of useful dehydration product, such as acrylic acid, during thermal desorption of the lactate-sorbed hydrotalcite was examined. The thermal desorption was performed at various temperatures in a tubular reactor with a nitrogen gas flow. The gaseous effluents were trapped and analyzed by HPLC and gas chromatography. Unfortunately, the major thermal decomposition products were carbon dioxide and water, resulting from complete decomposition of the lactate.

Treatment of the lactate-sorbed hydrotalcite with refluxing ethanol was also investigated. If the hydrotalcite, which contains both basic and acidic sites, could catalyze the esterification of the lactate, a useful ester (ethyl lactate) could be obtained, and the remaining organic materials could be thermally decomposed. Gas chromatographic analysis of the ethanol separated at the end of the refluxing period $(8 \mathrm{hr})$ showed that no ethyl lactate had formed. Addition of acid catalysts (sulfuric acid or boron trichloride) to the lactate-sorbed hydrotalcite suspension in refluxing ethanol also gave no ethyl lactate. Although the mineral acids are believed to release lactic acid from the hydrotalcite, they are neutralized by the hydrotalcite. Thus no catalyst remains for the esterification reaction.

\section{Ion-Exchange Resins}

Similar experiments were performed with an anion exchange resin to remove the lactate from the neutralized wastewater and convert the lactate to ester. In this case, the results demonstrated that ethyl lactate does form with the addition of acid to the system. The yields were low, however. This method could be further explored, but rapid fouling of the resin by the carbohydrate and protein material present may not make this approach commercially viable.

\section{Dual-Sorbent Ion Exchangers}

A new technology (Diazem Dual-Zone ${ }^{\mathrm{TM}}$ cartridges) is available for solid-phase extraction or sorption of organic matter from aqueous samples. This technology employs a 50-micron silicabased particle with dual phases consisting of different materials in the pores and on the outer surface. For this application, the phases were an anion exchanger coating (SAX) in the pores and a nonadsorptive fouling-resistant phase on the exterior.

The neutralized wastewater $(10 \mathrm{~mL})$ containing $9.2 \mathrm{mg} / \mathrm{mL}$ of lactate was passed through a bed containing $1 \mathrm{~g}$ of the activated Diazem particles. The effluent contained $2.1 \mathrm{mg} / \mathrm{mL}$ of 
lactate. Although this represented a respectable capacity for the exchanger, the effluent contained almost none of the impurities (sugars, betaine, and proteins). Thus the material was a complete failure for fouling resistance. Elution of the exchanger with sulfuric acid to recover lactate gave a poor recovery of lactate $(28 \mathrm{mg})$, but did remove a majority of the impurities. Further washing eluted more of the lactate. The regenerated material was utilized in a second cycle with $10 \mathrm{~mL}$ of the neutralized wastewater. The second batch of eluent contained $5.0 \mathrm{mg} / \mathrm{mL}$. Thus the capacity was significantly decreased. As before, the eluent was free of impurities. The exchanger was again regenerated and retested. The third cycle gave eluent containing $3.5 \mathrm{mg} / \mathrm{mL}$. The major problem is the large amount of solution needed to recover lactate from the column. The inefficient recovery makes it impossible to concentrate the lactic acid. The silica base was also probably attacked by the acid, since the flow rate decreased substantially in the second and third cycles.

\section{CONCLUSIONS}

The project established the feasibility of concentrating the lactic acid by freeze-thaw crystallization. A simulation was performed with sugar beet wastewater in a bench-scale freezethaw unit at B.C. Technologies. This experiment used a temperature sequence corresponding to typical midwestern winter conditions. Two brine fractions from the experiment were high in lactate ( 2.6 times the feed concentration of $7.82 \mathrm{~g} / \mathrm{L}$ ). The two brine samples represent $55 \%$ of the lactate recovered. Other carboxylic acids were similarly concentrated in the brine fractions. The lactic acid in two intermediate fractions has also been concentrated $(12.2$ and $9.1 \mathrm{~g} / \mathrm{L})$ with respect to the feed. Two of the treated water samples were very low in lactic acid and represent $35 \%$ of the feedwater. Thus, a substantial part of the product fractions could possibly be discharged without further treatment.

Although the simulation experiment resulted in a substantial quantity of lactic acid concentrate, the goal of a tenfold concentration of the lactic acid was not achieved. Since a single freeze experiment performed on the brine product resulted in a substantial further concentration, we know that there is no chemical or physical reason why the tenfold concentration or higher could not be achieved by repetition of the process and better controls. Some of the problem may have been the experimental difficulties in keeping the simulator temperatures as low as needed. As depicted in Figure 2, subzero temperatures were only rarely obtained, and these were only to about $-2^{\circ} \mathrm{C}$. Thus the normal midwestern January subzero temperatures were not reached. There were also quite a few high-temperature spikes as a result of maintenance required for feed line and recycle line freeze-ups.

A major question that is not yet answered is whether the concentration could be accomplished more effectively and easily if all the lactic acid were converted to calcium lactate. Presumably the salt form would be more effective in lowering the freezing point of water and could give a more efficient process. The disadvantage of calcium lactate is that the solubility product may be exceeded and precipitation might occur, giving an extra phase that could interfere with the simulation experiment. This experiment should be tried, nevertheless, and any phase difficulties might be resolved by filtration. 
Sugar beet wastewater can be purified by treatment with hydrotalcites or other inorganic anion exchangers, and the exchangers can be easily regenerated; but recovery of lactate from the exchangers as lactate or ester is extremely difficult. Other methods such as freeze-thaw crystallization are better for lactate recovery. 